\title{
Spontaneous pneumomediastinum and subcutaneous emphysema secondary to pulmonary alveolar microlithiasis
}

\author{
Fuat $\operatorname{EREL}^{1}$ (ID) \\ Candan GÜNGÖR ${ }^{2}(I D)$ \\ Nurhan SARIOĞLU ${ }^{1}($ ID) \\ Gülden Deniz AKSU ${ }^{1}$ (ID) \\ Gülay TURAN ${ }^{3}($ ID) \\ Gülen DEMIRPOLAT ${ }^{2}(\mathrm{ID})$
}

${ }^{1}$ Department of Chest Diseases, Balıkesır University Faculty of Medicine, Balıkesir, Turkey

1 Balıkesir Üniversitesi Tıp Fakültesi, Göğüs Hastalıkları Anabilim Dalı, Balıkesir, Türkiye

${ }^{2}$ Department of Radiology, Balıkesir University Faculty of Medicine, Balıkesir, Turkey

${ }^{2}$ Balıkesir Üniversitesi Tıp Fakültesi, Radyoloji Anabilim Dalı, Balıkesir, Türkiye

${ }^{3}$ Department of Pathology, Balıkesir University Faculty of Medicine, Balıkesir, Turkey

${ }^{3}$ Balıkesir Üniversitesi Tıp Fakültesi, Patoloji Anabilim Dalı, Balıkesir, Türkiye
Cite this article as: Erel $F$, Güngör $C$, Sarığlu N, Aksu $G D$ Turan G, Demirpolat G. Spontaneous pneumomediastinum and subcutaneous emphysema secondary to pulmonary alveolar microlithiasis. Tuberk Toraks 2021;69(3):416-420.

Address for Correspondence (Yazışma Adresi)

Dr. Candan GÜNGÖR

Department of Radiology, Balıkesir University Faculty of Medicine,

BALIKESIR - TURKEY

e-mail: candan_gungor@hotmail.com

CCopyright 2021 by Tuberculosis and Thorax.

Available on-line at www.tuberktoraks.org.com

\section{ABSTRACT \\ Spontaneous pneumomediastinum and subcutaneous emphysema secondary to pulmonary alveolar microlithiasis}

Pulmonary alveolar microlithiasis (PAM) is a rare autosomal recessive disease characterized by intraalveolar accumulation of microliths. PAM is described as the formation and accumulation of calcium phosphate microliths in the alveoli after mutations in the SLC34A2 gene. The patients may be asymptomatic or present with heterogeneous signs such as dyspnea, cough, sputum, weakness, chest pain and hemoptysis. Recurrent pneumothoraces may occur over the course of the disease in advanced cases. Her, it was aimed to report a case of a 40-year-old female presenting with chest pain, sore throat, cough and green sputum for the past two months. Chest radiography and computed tomography showed pneumomediastinum and subcutaneous emphysema which have not been reported in previous studies due to PAM. Bronchoscopy with bronchoalveolar lavage (BAL) and mucosal biopsy were done after pneumomediastinum had cleared. BAL result was concordant with pulmonary alveolar microlithiasis. Diagnosis can be made with computed tomography but may necessitate histopathological verification for definitive diagnosis.

Key words: Alveolar microlithiasis; pneumomediastinum; subcutaneous emphysema; tomography 


\section{ÖZ}

\section{Pulmoner alveoler mikrolitiazise sekonder gelişen spontan pnömomediastinum ve subkutan amfizem}

Pulmoner alveolar mikrolitiyazis (PAM), intraalveolar mikrolit birikimi ile karakterize, nadir görülen otozomal resesif bir hastalıktır. PAM, SLC34A2 genindeki mutasyonlardan sonra alveollerde kalsiyum fosfat mikrolitlerinin oluşumu ve birikmesi olarak tanımlanmıştır. Hastalar asemptomatik olabileceği gibi dispne, öksürük, balgam, halsizlik, göğüs ağrısı ve hemoptizi gibi heterojen belirtiler de gösterebilir. Hastalığın seyri boyunca, ileri vakalarda tekrarlayan pnömotoraks atakları meydana gelebilir. Biz son iki aydır göğüs ağrısı, boğaz ağrısı, öksürük ve yeşil balgam şikayetleri ile başvuran 40 yaşındaki bir kadın hastayı sunuyoruz. Göğüs radyografisi ve bilgisayarlı tomografide (BT), pulmoner alveolar mikrolitiazise bağlı mikronodüllere ek olarak, daha önce bilimsel yayınlarda bildirilmeyen pnömomediastinum ve subkutanöz amfizem görüldü. Pnömomediastinum geriledikten sonra bronkoskopi ile bronkoalveolar lavaj (BAL) ve mukozal biyopsi örneklemeleri yapıldı. BAL sonucu pulmoner alveolar mikrolitiyazis ile uyumlu olarak geldi. Tanı bilgisayarlı tomografi ile konulabilir ancak kesin tanı için histopatolojik verifikasyon gerekebilir.

Anahtar kelimeler: Alveoler mikrolitiazis; pnömomediastinum; subkutan amfizem; tomografi

\section{INTRODUCTION}

Pulmonary alveolar microlithiasis (PAM) is a rare lung disease characterized by widespread accumulation of calcium in the alveoli. Although patients are generally asymptomatic, there are some radiological findings detected incidentally (1). In radiological examinations, calcific micronodules with a diameter of 1-3 $\mathrm{mm}$ have been identified, which typically cause a "sand storm" appearance (2). First presentation with clinical signs of pneumothorax is very rare (5). To the best of our knowledge, there have been no reports about presentation with spontaneous pneumomediastinum and subcutaneous emphysema in the literature so far. In this case report, we aimed to present the clinical and radiological findings of our patient with a diagnosis of PAM confirmed by bronchoscopic lavage, who applied to our hospital with spontaneous pneumomediastinum and subcutaneous emphysema.

\section{CASE}

A 40-year-old female patient presented with chest pain, sore throat, cough and green sputum for the past two months. She was hospitalized in another hospital for one month with a diagnosis of viral pneumonia. She was referred to our hospital due to increase in dyspnea, weakness and weight loss and no clinical and radiological improvement despite treatment. She had a smoking history of 10 packs/ year. There was no environmental contact and animal breeding in medical history. On physical examination, she was cachectic; also, dyspnea, tachypnea and cyanosis were observed.

There were crepitations around the neck and chest suggesting subcutaneous emphysema. Complete Blood Count, sedimentation rate, C-reactive protein and routine biochemical tests were found normal. On a chest X-ray, curvilinear and linear lucencies were observed around the aortic knob, and the subcutaneous tissue in the neck and the chest. On lateral X-ray, ring shape lucency was observed around the pulmonary artery, as well (Figure 1). In addition, diffuse opacification due to micronodules was observed in both lungs. CT examination showed ground glass micronodules in sizes of 1-2 $\mathrm{mm}$ in the middle and upper zones in both lung parenchyma. Subcutaneous emphysema spreading to the neck compartments, retropharyngeal space, back and axilla was observed (Figure 2,3).

The patient was started on oxygen treatment and nonspecific antibiotherapy. Sputum smears were negative for acid-fast bacilli. Bronchoscopy with bronchoalveolar lavage (BAL) and mucosal biopsy were done after disappearance of pneumomediastinum. Mucosa was hyperemic, and there were no endobronchial lesions. The pathology result was concordant with pulmonary alveolar microlithiasis (Figure 4). There was no bacterial or mycobacterial growth on culture.

Partial improvement was observed in the clinical findings of the patient. Spontaneous pneumomediastinum and subcutaneous emphysema findings regressed on control CT images one month later (Figure 5). Oxygen support at home, influenza and pneumococcal vaccines were planned. The patient was referred for transplantation preparation but died due to respiratory failure approximately two months after being discharged from the hospital.

\section{DISCUSSION}

PAM is a rare lung disease characterized by calcium deposition into alveoli called microliths. It was first described by an Italian scientist, Marcello Malpighi, in 1868. Afterwards, in 1918, radiologic findings were described by Harbitz. In 1933, the disease was named PAM by the pathologist Ludwing Puhr. Until 


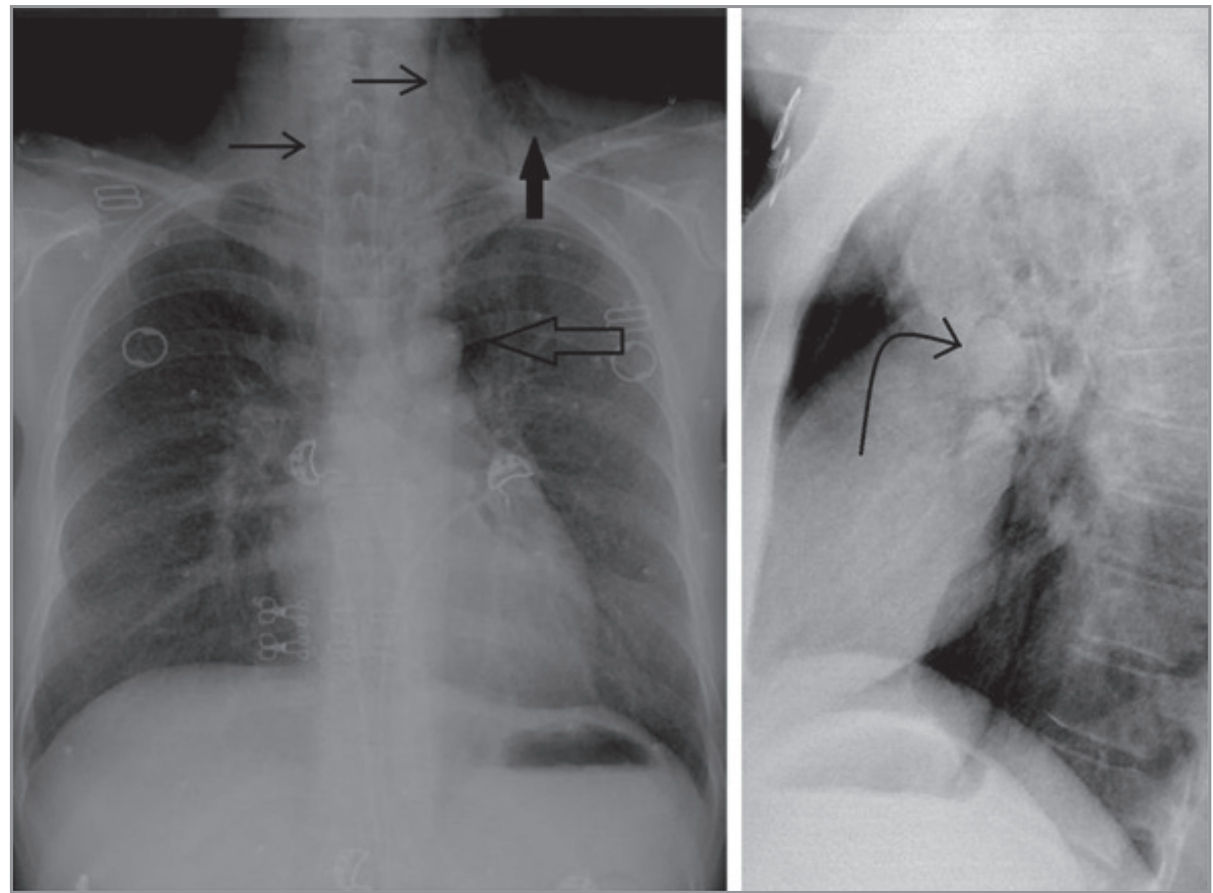

Figure 1. Chest $X$ radiograph, $P A$ and lateral views; Opacification in the parenchyma due to micronodules. Free air around the aortic knob and pulmonar artery (hollow arrow, curved arrow). Tubular vessel sign (thin arrow). Subcutaneous emphysema (filled arrow).
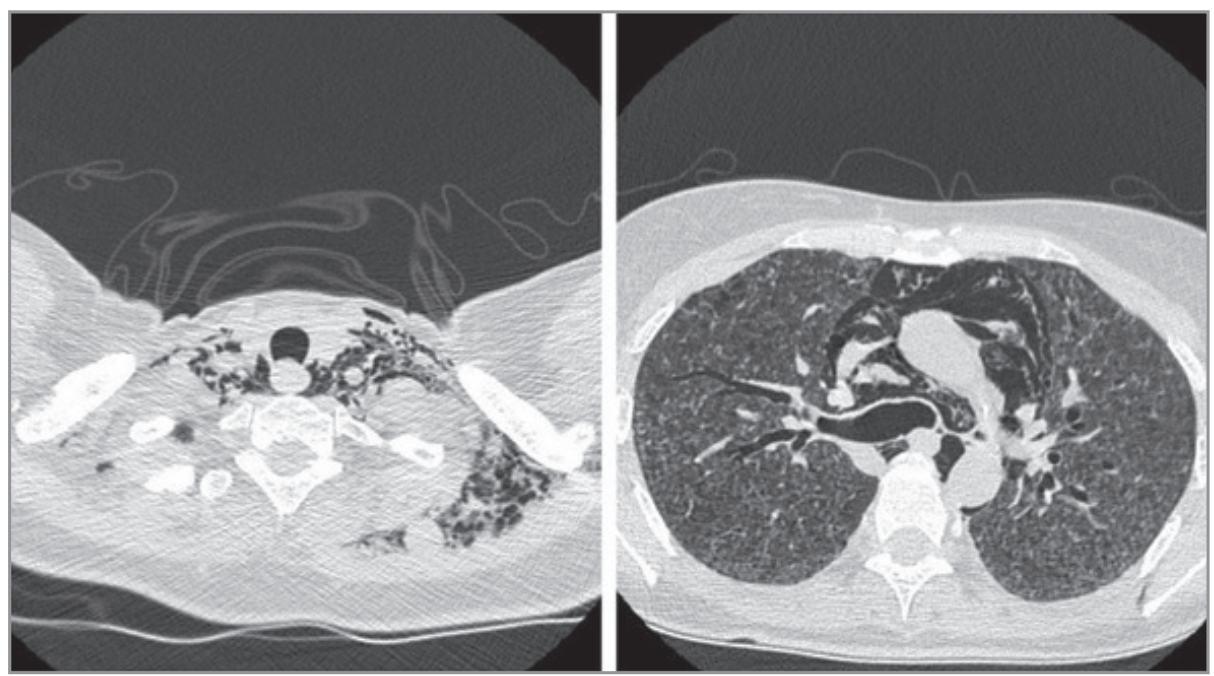

Figure 2. Axial CT images; There is widespread air around the heart, adjacent to the vascular structures, neck compartments and subcutaneous tissue. Note pre-calcified micronodules of 1-2 mm in size in both lung parenchyma.

today, over 1200 cases have been reported around the world, of which half have been seen in Turkey, China, Japan, Italy, and India (1).

Although PAM is seen in all ages, it is more common in the second and third decades. One third of the cases are familial, and the rest are sporadic. While the female sex seems to be predominant in familial cases, the male sex seems to be predominant in sporadic ones (1). PAM is considered to be an autosomal recessive disorder. In 2006, SLC34A2 mutations were identified as the gene responsible for the disease by 


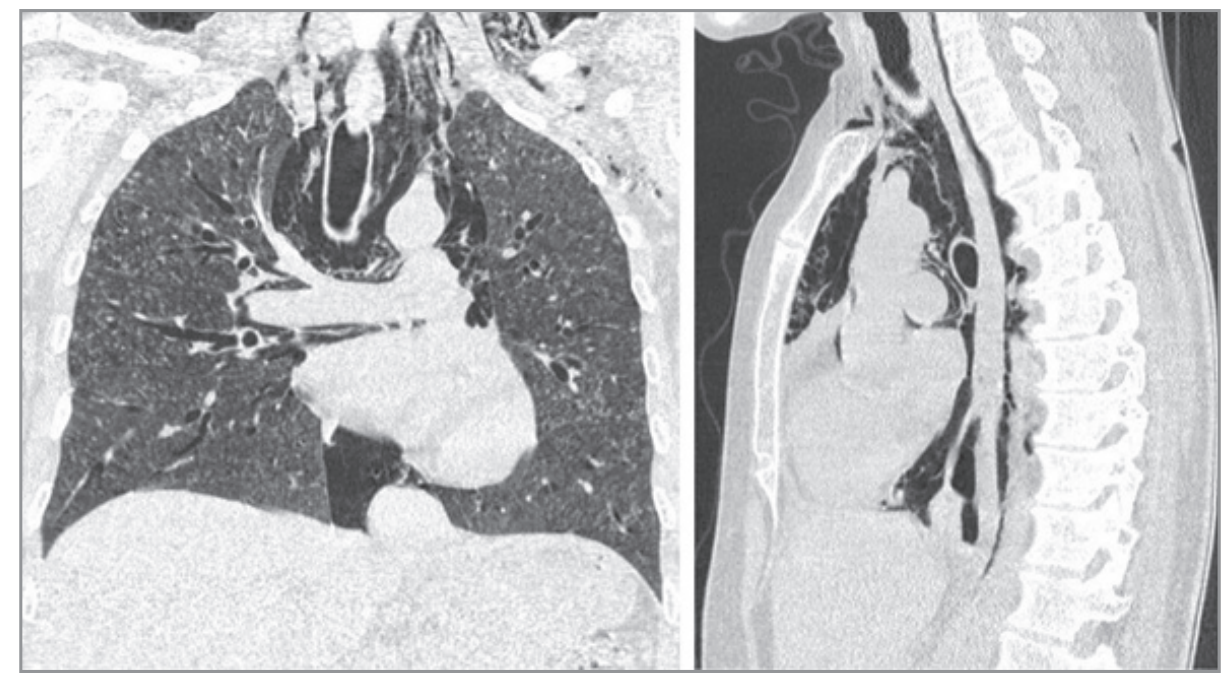

Figure 3. Coronal and sagittal reformatted CT images; There is widespread air around the heart, adjacent to the vascular structures, neck compartments and subcutaneous tissue. Note pre-calcified micronodules of 1-2 $\mathrm{mm}$ in size in both lung parenchyma.

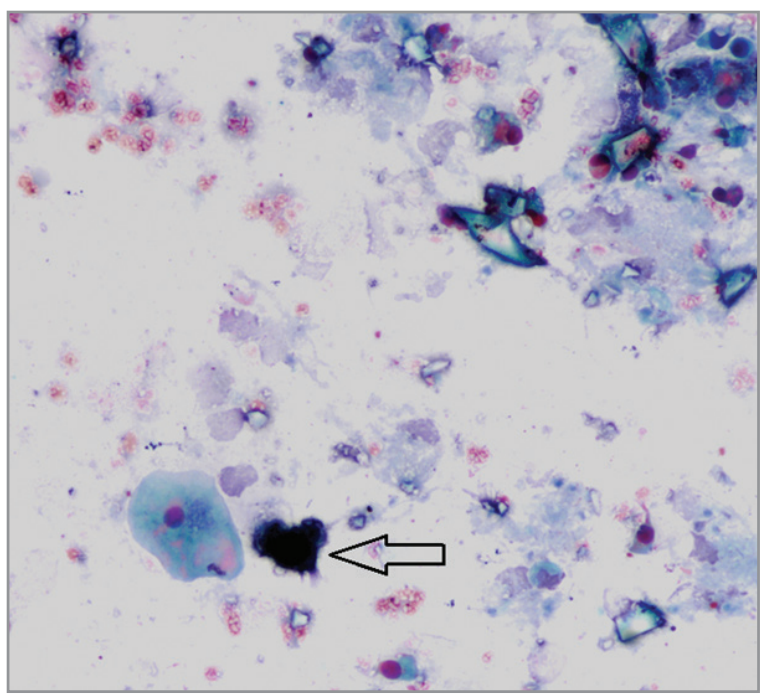

Figure 4. Bronchoalveolar Lavage (BAL) sample; papanicolaou staining shows concentric-looking calcified body (arrow), (x200).

homozygosity mapping (2). This gene encodes the sodium dependent phosphate carrier, which is important for type II pneumocytes. Due to the defect in this gene, phosphorus ions cannot be transported into the alveoli and as a result, microliths composed of calcium and phosphate accumulate in the alveoli (3).

The clinical traits can remain silent for many years, and many patients can be diagnosed incidentally (4). The most common symptoms are dyspnea, cough, sputum, weakness, chest pain and hemoptysis $(5,6)$.
Recurrent pneumothoraxes may occur over the course of the disease. It occurs as a result of opening of the subpleural cysts into the pleural space. Rarely, the first presentation of the PAM case may be the formation of pneumothorax (7). Our case had a spontaneous pneumomediastinum and subcutaneous emphysema clinic. No other cases of pneumomediastinum arising in this way or during the course of the disease have been identified in the English literature. In PAM Chest $\mathrm{X}$-ray and $\mathrm{CT}$ findings are variable depending on the phase of the disease. The first phase starts with diffuse pre-calcified micronodules $\quad<1$ $\mathrm{mm}$ ). In the second phase, micronodules begin to calcify. The appearance in the lungs is known as "sand-storm". In the third phase, there is an increase in the number and volume of nodules. In addition to the nodules, thickening of interstitial structures is observed. Finally, in the fourth phase, there is intense calcification of the interstitium and sometimes the pleura (1). The 'crazy paving' pattern with calcifications along the interlobular septa may be considered diagnostic, even pathognomonic, of the third and the fourth phases of PAM (8). In addition, subpleural cysts have been identified at an advanced stage, and these cysts cause a "black pleura" sign on the radiograph. $\mathrm{CT}$ of our patient showed diffuse pre-calcific micronodules distributed in the middle and upper zones which fitted the first phase of the disease.

Differential diagnosis of pulmonary alveolar microlithiasis includes miliary tuberculosis, sarcoidosis, 


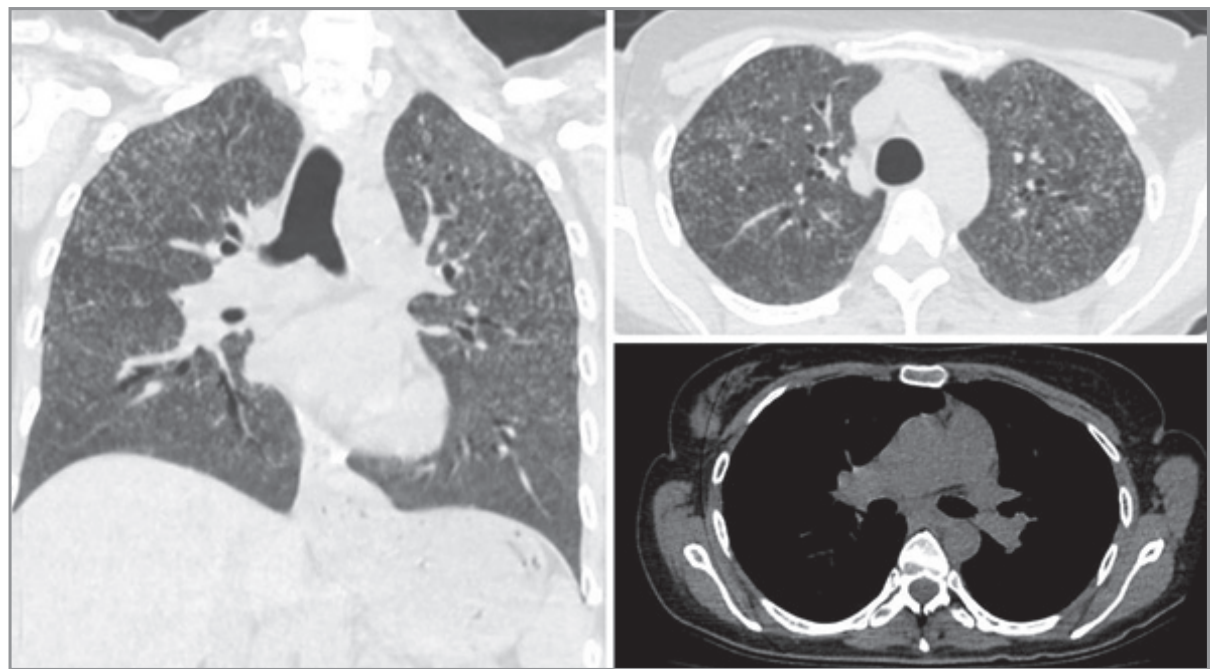

Figure 5. Axial and coronal reformatted CT images; Free air regressed completely in the mediastinum and subcutaneous tissues one month after spontaneous pneumomediastinum treatment. Note pre-calcified micronodules of 1-2 $\mathrm{mm}$ in size in the middle and upper zones.

hemosiderosis, and amyloidosis. The micronodules of miliary tuberculosis are not calcified. Sarcoidosis and pneumoconiosis have upper lobe predominant, perilymphatic and paraseptal distributed nodules. BAL and bronchoscopic forceps biopsies are usually performed to confirm the diagnosis in all cases. Histological examination shows microliths in the alveolar spaces. Identification of the SLC34A2 gene mutation could make the diagnosis definite.

No effective treatment for PAM is known except for lung transplantation. In the last period of the disease, patients are lost as a result of respiratory failure and cor pulmonale. In conclusion, PAM is a rare lung disease. Although presentation with spontaneous pneumothorax has been reported, our patient is the first case in the English literature presenting with pneumomediastinum and subcutaneous emphysema.

\section{CONFLICT of INTEREST}

The authors reported no conflict of interest related to this article.

\section{AUTHORSHIP CONTRIBUTIONS}

Concept/Design: FE, GD, NS

Analysis/Interpretation: CG, GD, FE

Data Acquisition: GDA, CG

Writing: CG, GDA

Critical Revision: GD, FE, NS

Final Approval: FE, GD

\section{REFERENCES}

1. Castellana G, Castellana G, Gentile M, Castellana R, Resta O. Pulmonary alveolar microlithiasis: review of the 1022 cases reported worldwide. Eur Respir Rev 2015; 24(138): 607-20.

2. Corut A, Senyiğit A, Uğur SA, Altın S, Özçelik U, Çalışır $H$, et al. Mutations in SLC34A2 cause pulmonary alveolar microlithiasis and are possibly associated with testicular microlithiasis. Am J Hum Genet 2006; 79(4): 650-6.

3. Saito A, McCormak FX. Pulmonary alveolar microlithiasis. Clin Chest Med 2016; 37(3): 441-8.

4. Erelel $M$, Çuhadaroğlu Ç, Kıyan E, Yılmazbayhan D, Kılıçaslan Z, Tunacı A. Alveolar microlithiasis - because of two siblings. Tuberk Toraks 2000; 48(3): 254-8.

5. Soytürk AN, Argüder E, Karalezli A, Hasanoğlu HC. A case of pulmonary alveolar microlithiasis with Sjögren's syndrome Tuberk Toraks 2013; 61(3): 258-9.

6. Ferreira Francisco FA, Pereira e Silva IL, Hochhegger B, Zanetti G, Marchiori E. Pulmonary alveolar microlithiasis. State-of-the-art review. Respir Med 2013; 107(1): 1-9.

7. Sigari N, Nikkhoo B. First presentation of a case of pulmonary alveolar microlithiasis with spontaneous pneumothorax. Oman Med I 2014; 29(6): 450-3.

8. Delic JA, Fuhrman CR, Bittar HET. Pulmonary alveolar microlithiasis: AIRP best cases in radiologic-pathologic correlation. RadioGraphics 2016; 36(5): 1334-8. 